\title{
THE ECONOMICS OF LANDFILL MINING SHREDDER RESIDUE - FOCUS ON THE AFTERCARE
}

\author{
R. M. ROSENDAL \\ Danish Waste Association, Vodroffsvej 59, 1. Sal, DK-1900 Frederiksberg C, \\ Denmark
}

SUMMARY: The main part of shredder residues produced in Denmark is landfilled. It is well known that shredder waste contains resources that can be recycled or incinerated with energy recovery. Thus, it is a better solution than landfilling the material.

The Danish Government launched its Resource Strategy in the summer 2014 with the objective that shredder residues ought to be landfill mined towards 2024. Consequently, prelandfilled shredder waste should be excavated and up-cycled. The effect of this initiative can be seen in figure 1.

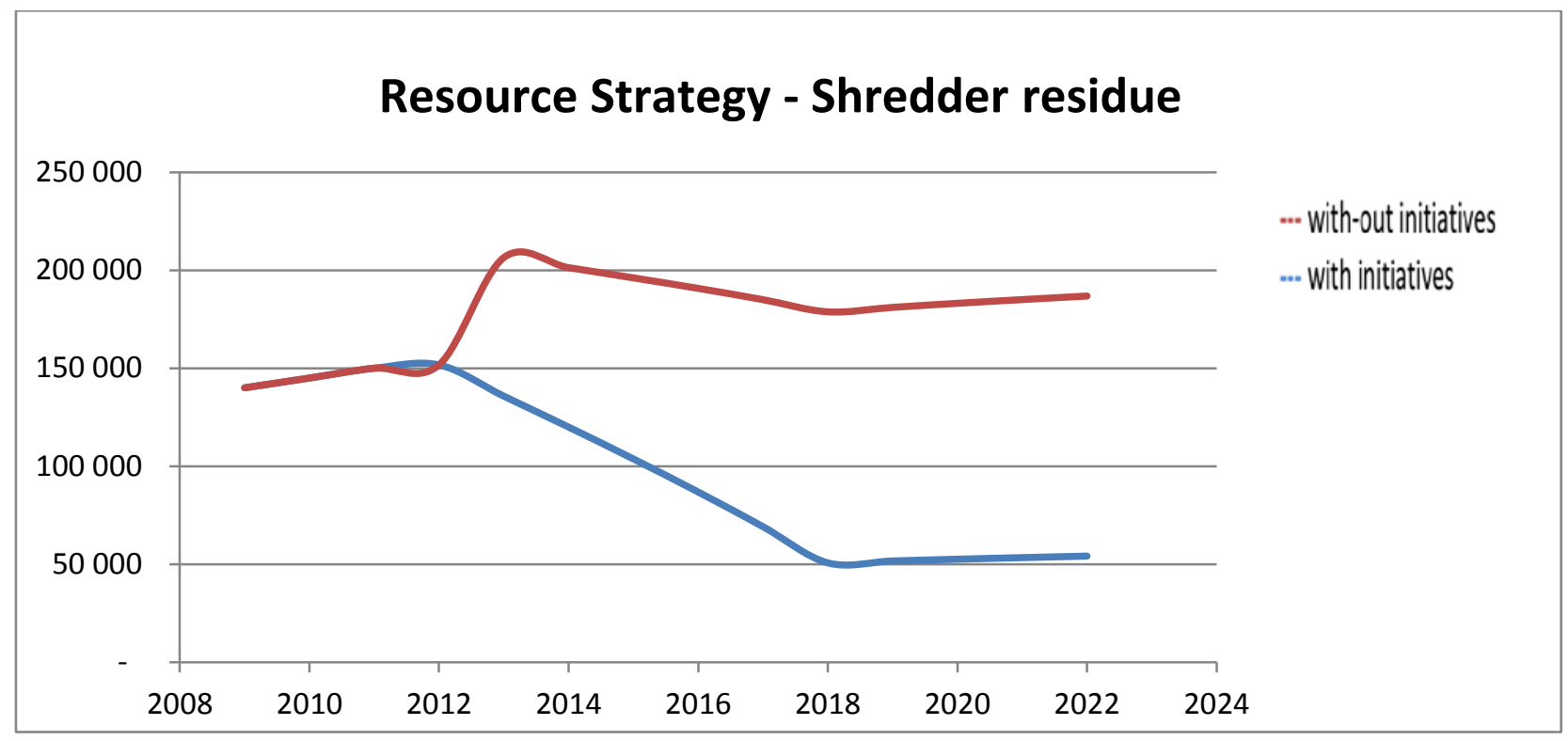

Figure 1: Resource Strategy with and without initiatives /7/

In general, terms following article describes some of the differences, barriers, and externalities concerning landfill mining of waste. Furthermore, it addresses the costs and economics of mining shredder waste from a landfill sites in Denmark with the focus on the aftercare costs and externalities

https://doi.org/10.15626/Eco-Tech.2014.015 


\title{
Linnaeus ECO-TECH` 14
}

\author{
Kalmar, Sweden, November 24-26, 2014
}

\section{INTRODUCTION}

Landfill mining (LFM) and reclamation is a process whereby previously landfilled solid waste is excavated and processed, typically from an active or closed landfill.

The function of LFM is to reduce the amount of landfill mass encapsulated within the closed landfill and/or temporarily remove hazardous material to allow protective measures to be taken before the landfill mass is replaced. In the process, LFM recovers valuable recyclable materials, a combustible fraction, soil, and landfill space. The aeration of the landfill soil is a secondary benefit regarding the landfill's future use. Furthermore, the overall appearance of the LFM procedure is a sequence of processing machines laid out in a functional conveyor system. The operating principle is to excavate, sieve, and sort the landfill material.

Typically, processing involves a series of mechanical processing operations designed to recover former landfilled materials. In addition, LFM can be used as a measure to remediate poorly designed or improperly operated landfills as well as to upgrade landfills that do not meet environmental and public health specifications $/ 4 /$.

Excavators, screens, and conveyors are typical equipments used in simple LFM operations. Complex LFM operations recover additional materials and improve the purity of recovered materials. Therefore, additional equipment is used to that of simple operations.

LFM projects have been carried out throughout the world during the last 50 years /11/ with different purposes such as:

- Conservation of landfill space

- Reduction in landfill area

- Expanding landfill lifetime

- Elimination of a potential source of contamination

- Mitigation of an existing contaminated source

- Energy recovery

- Recycling of recovered materials

- Reduction in management system costs (aftercare costs)

- Site re-development

In general, a LFM project involves a significant financial investment and an element of risk. Excavation of landfill is associated with varying financial conditions, depending on the composition of the waste deposited at the landfill as well as opportunities for the re-use of materials found. Hence, the individual LFM companies will demand an accurate insight in its profit potential before making the final decision to initiate the project.

The costs are often offset by the sale or use of recovered materials, e.g. recyclables, soil, and waste, which, can be incinerated as fuel. Other important benefits may include avoided liability through site remediation, reductions in closure costs, and reclamation of land for other purposes. 


\title{
Linnaeus ECO-TECH` 14
}

\author{
Kalmar, Sweden, November 24-26, 2014
}

It is well-known that LFM reduces or eliminates closure costs and, in most cases, reduces the long-term environmental problems. Despite its many benefits, some potential limitations exist to LFM of waste.

\section{Economic aspects}

Traditionally, the economics of LFM is dependent on the depth of the waste material and the ratio soil-to-waste. Thus, the deeper the waste is buried, the more expensive a site is to reclaim per hectare. Furthermore, the lower the soil-to-waste ratio is, the more material must be either reburied or transported for disposal off site.

It is usually believed that the recyclables recovered might provide economic revenue depending on several aspects, such as the quality of the separated fractions, local situation, and the market price. In specific circumstances, recovery focused on ferrous metals, aluminium, plastic, glass as well as fine organic and inorganic material can have economic significance if they represent significant volume for recovery. The before mentioned may be true with regards to the industrial landfills as well as the car fragmentation and scrape dealing industry. Industrial landfill with toxic contents, e.g. old glass factories and battery factories, may be very expensive to reclaim. Even though the existence of a vast amount of high-quality LFM site candidates and land reclamation can be estimated, such strategy is seldom applied mainly due to lack of information and the way of making the economic evaluations of' the projects.

The accounting of economic benefits of a LFM project must be comprehensive and include reduction or elimination with respect to the need for: capping, long-term monitoring and after case, maintenance and potential remediation costs, effective use and logistics of machinery, increased value of the reclaimed land, and avoidance of finding a new site and infrastructure costs in the case the reclaimed land is used for constructing a new landfill. A positive aspect only recently appreciated that companies are able to earn carbon credits stopping methane and carbon dioxide escaping to the atmosphere. New tools to facilitate the financial reviewing and following-up the operational phase of the LFM must be developed. Therefore, legislative peculiarities must be considered due to the local and EU regulations. LFM can be seen as part of the integrated solid waste management, which means that in Europe the fraction to be disposed at a new landfill shall be sorted out for recoverable and treated for organic waste.

The costs and benefits of LFM vary significantly depending on (a) the objectives of the project, e.g. closure, remediation, new landfill, (b) site-specific landfill characteristics, e.g. material disposed, waste decomposition, burial practices, age and depth of fill, and (c) local economics, e.g. value of land, cost of closure materials, and monitoring, /10/ /4/. Cost heads related to project planning include capital and operational costs of the LFM project as such as:

- Site preparation

- Rental or purchase of reclamation equipment

- Rental or purchase of personnel safety equipment

- Construction or expansion of materials handling facilities

- Rental or purchase of hauling equipment

- Labour, e.g. equipment operation and materials handling

- Equipment fuel and maintenance

- Administrative and regulatory compliance expenses, e.g. record keeping 


\section{Linnaeus ECO-TECH` 14}

\section{Kalmar, Sweden, November 24-26, 2014}

- Worker training in safety procedures

- Hauling costs

The most potential economic benefits associated with landfill reclamation are indirect. However, a project can generate revenues if markets exist for recovered materials. Although the economic benefits from reclamation projects are facility-specific, they may include any or all of the following:

- Increased disposal capacity

- Avoided or reduced costs of:

o landfill closure

o post closure care and monitoring

o purchase of additional capacity or sophisticated systems

o liability for remediation of surrounding areas

- Revenue from:

o recyclable and reusable materials, e.g. ferrous metals, aluminium, plastic, and glass

o combustible waste sold as fuel

o reclaimed soil used as cover

o materials sold as construction fill or sold for other purposes

o land value of sites reclaimed for other purposes

In general, the economics of LFM depend on the depth of the waste material and the ratio of waste to soil. The deeper the waste is buried, the more expensive a landfill per unit area is to reclaim (Salerni, 1995). In most cases, the presence of hazardous materials will also affect the economic feasibility. Thus, this step in project planning of analysing the economics of LFM calls for the investigation of following areas:

- Current landfill capacity and projected demand

- Projected costs for landfill closure or expansion of the site

- Current and projected costs of future liabilities

- Projected value of land reclaimed for other purposes

- Projected markets for recycled and recovered materials

- Projected value of land reclaimed for other purposes

In addition to avoiding the cost and time of locating, designing, permitting, and constructing a new landfill, the major benefit with latter approach is that existing landfills extend their operating life by many years.

The analysis of dumpsite mining economics calls for the investigation of: (a) current capacity and projected demand of the landfill, (b) projected costs for landfill closure or expansion of the site, (c) current and projected costs of future liabilities, (d) projected markets for recycled and recovered materials, and (e) projected value of land reclaimed for other purposes. Major 


\section{Linnaeus ECO-TECH` 14}

\section{Kalmar, Sweden, November 24-26, 2014}

factors influencing the cost of such projects will include the volume and topography of the dumpsite, equipment parameters, soil conditions, climate, labour rates, the regulatory approval process, excavation and screening costs, sampling and characterisation, development costs, the contractors' fees, hazardous waste disposal, and revenue from the sale of commodities such as compost and recyclables.

In practice, the environmental costs and benefits ought to be added to the project costs and benefits before applying decision criteria as Net-Present Value, Benefit-Cost Ratio, or the Internal Rate of Return. The main challenge is to properly estimate the environmental costs and benefits. Unlike the more tangible project costs and benefits, the estimation of environmental costs and benefits is more complicated. As such, no data is currently available to monetise the local environmental benefits arising from the control of smoke and air pollution because of the open burning of garbage and control of door and fly nuisance as well as ground water pollution due to leachate.

Benefits can be organised in two main categories: (1) benefits related to more efficient operation of landfills and (2) benefits related to recyclables and regained land. In contrast, costs are distinguished in capita costs and operational costs. Some remarks on the overview are as follows:

- Costs and benefits from reclamation projects are facility-specific, any or all may appear in a specific LMF project.

- Subsidies from (local) authorities or third parties are not mentioned as a potential benefit. In addition, efforts involved in researching costs and benefits of LFM projects are not made explicit in the overview.

- A pro-active market approach towards LFM may imply the purchase of landfills.

The overview implies a strict division in capita costs and operational costs. In some cases nevertheless, this is not clarified. For example, work training in safety procedures may concern a one-time exercise; however, it may also refer to an activity that is carried out on a regular basis in order to guarantee a certain routine in meeting the requirements.

In general, a mining project involves a significant financial investment and is not free of risks. Therefore, the respective mining companies will demand an accurate insight in its profit potential before making the final decision whether to initiate the project. Such insight has to be obtained as the net result of a rather elaborate investigation preceding the actual mining activities. It involves a multitude of research efforts such as analysing samples of the landfills' contents and the acquirement and interpretation of local regulations and development plans.

For a single project, such efforts may be acceptable. However, this is no feasible alternative for a large set of projects on account of the required time and amount of costs and resources involved. In this subsection, we try to solve abovementioned dilemma by strongly reducing the number of landfills considered for the elaborated investigation through the use of more simple research means. 


\section{BACKGROUND AND AIM}

In Denmark, shredder residue is classified as hazardous waste. Up until the beginning of 2012, landfilling was the only way to manage and disposal waste. In 2012, a temporary permission for incineration of a fraction of shredder residue was given.

Regarding landfilling, the waste tax on hazardous waste was partly introduced 1 January 2012 with $€ 21.33 \mathrm{pr}$. ton. In addition, the waste tax is scheduled to full implementation 1 January 2015 with €63.33 pr. ton. It is expected that the full waste tax will have a vast impact on the quantity of shredder residue, which is to be forward-looking landfilled. Moreover, it is expected that the Danish Environment Protection Agency will set requirements concerning recycling of resources from recent generated shredder residue in the near future.

By the year of 2015, the objective is that the resources in shredder residue will be better exploited and the quantity for landfilling will be significantly reduced without containing recyclable resources.

By the end of 2012, it is estimated that more than 1.9 million tons of shredder residue are situated at mono landfills at Odense Renovation, Reno Djurs I/S, AV Miljø, and Nomi 4S containing resources in the form of materials - especially metal - and energy, i.e. resources that can be reclaimed by LFM.

The objective is to clarify a number of corporate economic conditions connected to LFM of landfilled shredder residue.

As a basis for the specific considerations regarding LFM, the memorandum will identify the significant cost factors as well as estimate the amount of these factors. The premise is that the landfill site owns landfilled waste. Hence, the economic conditions are to be viewed from the landfill site's part.

A number of cost factors will be site-specific. In this connection, the memorandum is based on site-specific data from Reno Djurs I/S's landfill site near Glatved Strand, Jutland.

Concerning specific considerations regarding LFM of shredder residue, the objective of the memorandum is to state the important cost factors that ought to be attached significance. Since a number of the stated cost factors may vary or be connected with considerable uncertainty, it must depend on case-specific evaluations whether LFM of shredder residue can be viewed as a good idea.

\section{METHOD - COSTS AND REVENUES}

Positive and negative costs tied up in LFM will be presented in the subsequent.

The rational is as follows; from a business economic perspective, LFM can be regarded as a good idea if the total of positive and negative costs tied up in LFM generates a positive or at a minimum a cost-neutral result.

The following cost components are included in the calculation: 
Negative:

1. Excavation costs

2. Sorting/processing costs

3. Transportation/removal costs

4. Incineration costs

5. Landfilling costs

Positive:

6. Proceeds from sale of marketable (recycling) material

7. Proceeds from released landfill volume

8. Reversal of government tax

9. Reversal of collateral security

10. Aftercare length uncertainty

The presented outline does not contain costs to administrative and managerial tasks involved in the excavation and processing of waste from a landfill site. These tasks consist of e.g. planning, authority application and contract, operation management, regulatory scrutiny, and reporting. A concrete evaluation must determine whether the aforementioned tasks are to be considered as an integral part of the landfill site's operation or if there is basis for projectrelated pricing of them.

Regarding the waste collected collateral, it is worth noting that the outline does not include considerations with regards to its ability to cover the actual costs for finishing treatment related to the waste in the landfill site's active period.

In the following, the individual posts are to be specified including preconditions of pricing and potential uncertainties.

Moreover, the pricing is indicated as $€ /$ ton. It is noted that infiltration of rainwater over landfilled shredder residue changes the waste's specific gravity. Thereby, a volume unit of landfilled waste will be heavier by removal than by supply. In other words, more waste can be removed than supplied in relation to weight.

No.1: Excavation costs

Excavation costs include contractors' costs for excavation of landfilled shredder residue.

\section{No.2: Sorting costs}

Sorting costs consist of contractors' costs for sorting. The size of costs will increase with the fineness of sorting. In addition, the sorting out of recyclable metals will imply larger costs than sorting out of an e.g. fraction suitable for incineration. Thus, the relation between the increments obtained by work up excavated shredder residue and the costs of reprocessing is crucial for LMF's economic sustainability. 


\section{Linnaeus ECO-TECH` 14}

\section{Kalmar, Sweden, November 24-26, 2014}

\section{No.3: Transportation/removal costs}

Transportation/removal costs cover transportation of excavated material for reprocessing and treatment plants. In this context, cost is indicated as the average transportation price on the quantity of excavated waste removed from the landfill unit/site.

Provided that the excavated material is not sorted internally at the landfill unit, the costs comprise both onward transportation of excavated material for screening plants and onward transportation of sorted out material for further reprocessing and treatment including possible recycling of fraction suitable for landfilling.

\section{No.4: Incineration costs}

Incineration costs include incineration of possible fraction suitable for incineration at a plant specially provided for this purpose.

In relation to this cost element, it is important whether the fraction suitable for incineration is characterised as hazardous waste or non-hazardous waste due to the following reasons:

\section{- Incineration charges}

In waste incineration, a charge is generally payable according to the calorific power or energy; cf. Statutory Order on Waste Taxes.

- Incineration capacity

Very few traditional waste incineration plants have the sanction to incinerate hazardous waste. Sampling of a waste fraction suitable for incineration requires that necessary capacity for incineration is provided.

\section{No. 5: Landfilling costs}

Landfilling costs comprise (re-) landfilling of the amount of excavated shredder residue, which cannot be utilised by material recycling or energy recovery.

The re-landfilling of shredder residue fractions suitable for landfilling including the costs hereof can be viewed from the following two considerations, which each has its implications:

- $\quad$ Scenario A: The landfilling fraction remains at the landfill site

The shredder residue fraction suitable for landfilling remains at the landfill site. Thus, it is solely waste utilised by material recycling or energy recovery that is removed.

Seeing that already landfilled waste remains at the landfill site, re-characterisation of the waste will not be performed. In addition, new fees for landfilling will not be imposed.

\section{- $\quad$ Scenario B: The landfilling fraction is re-landfilled}




\section{Linnaeus ECO-TECH` 14}

\section{Kalmar, Sweden, November 24-26, 2014}

All excavated shredder residue is removed for sorting/reprocessing. The fraction of waste not utilised by material recycling or energy recovery is retraced to the landfill site as "new” waste.

Due to the fact that it is a question of "new" waste, the authorizing municipality must characterise the waste fraction as hazardous or non-hazardous waste. In relation to hazardous waste, the waste fraction must be further characterisation tested cf. the Statutory Order on Landfilling's Provision thereof.

The waste is imposed the landfill site's charge on the particular kind of waste suitable for landfilling. In the case of non-hazardous waste, a governmental tax is imposed equivalent to $€ 66.33 /$ ton cf. "Act on Waste and Raw Material Taxes”. In contrast, the governmental tax imposed on hazardous waste is equivalent to $€ 21.33 /$ ton for the period 2012-2014. In 2015, the tax will increase to €63.33/ton including a gate fee.

\section{No. 6: Proceeds from sale of marketable (recycling) material}

Proceeds are defined by the current market price for the selected materials of the required quality.

In pursuance of Environmental Project 1440, 2014 (p. 57), metals for an estimated value of $€ 26.66$ - 66.66/ton excavated shredder residue can be reclaimed.

No. 7: Proceeds from released landfilling volume

Proceeds are defined as the value of volume released by removal of waste.

Costs per volume unit are calculated based on the community's costs for the establishment of the operational landfill sites that were put into operation in 2009.

Proceeds from released volume of landfilling will increase concurrently with costs for procurement of new landfilling capacity are increased due to increased prices on area acquisition and site costs.

In order for re-landfilling to take place in accordance with existing set of rules, it must be noted that released volume is only recyclable, i.e. to replace new volume of landfilling as long as the landfilling units are technologically up-to-date.

\section{No. 8: Reversing of governmental tax}

In accordance with "Act on Waste and Raw Material Taxes", tax on waste delivered at a registered site has to be paid. Landfilling sites that receive waste covered by the municipal council's assignment or collection scheme are required to register.

Running to the end of 2011, the Act on Waste Taxes comprised specific provisions that allowed hazardous waste to be landfilled exempt for taxation. 


\section{Linnaeus ECO-TECH` 14}

\section{Kalmar, Sweden, November 24-26, 2014}

As a result, "specific sites for landfilling hazardous waste” were exempt of duty to register up to the end of 2009. The provision for exemption registration involved that the sites did not receive other authority-assigned waste.

On and with effect from 2010, the special-purpose sites for hazardous waste were imposed duty to register. In the period 2010-2011, the tax was fixed at \$0/ton (Act on Waste Taxes' section 10 (1, 2) and exhibit 3). Within the period 2012-2014, waste of same kind was imposed a reduced tax fixed at $€ 21.33 /$ ton (Act on Waste Taxes' section $10(1,2)$ and exhibit 3).

In case of respectively landfilling of hazardous waste and landfilling of other waste, the tax will be fixed at the same price from 1 January 2015, i.e. currently at €81.33/ton.

The changes in government tax on landfilling of hazardous waste are shown in table 1 below.

\begin{tabular}{|l|l|l|l|l|l|l|}
\hline & 2010 & 2011 & 2012 & 2013 & 2014 & 2015 \\
\hline$€ /$ ton & - & - & 21.33 & 21.33 & 21.33 & 63.33 \\
\hline
\end{tabular}

Table 1: The changes in government tax on landfilling of hazardous waste

Within the Act on Waste Taxes, it is a point of principle that registered companies must calculate the taxable weight for a tax period based on the quantity of waste supplied for landfilling, deducting the weight of quantity that is removed once again. Tax for additional weight is reimbursed in case the weight of removed waste is larger than that of supplied.

Put in a different way, tax on already supplied waste is deducted, i.e. reversed to current rate of tax, if waste is removed from the registered site.

Subject to the amendment to the Act of 4 July 2013, a new provision is inserted, i.e. section 12 (2). With regards to hazardous waste, the new provision states that deduction in tax liability with the value in pursuance of rate of tax in force at the time the waste is supplied to the landfill site can occur.

Hence, the unit cost is fixed at:

- $\quad € 0 /$ ton for waste landfilled until 2012

- $\quad € 21.33 /$ ton for waste landfilled within the period 2012-2015

- $\quad € 63.33 /$ ton for waste landfilled after 2015

\section{No. 9: Proceeds from reversal collateral security}

Every landfill site approved according to the Statutory Order on Landfilling must provide security for future, predictable costs generated by received waste. The basic assumption behind the establishment of collateral security is that the landfilling of one ton of waste 


\section{Linnaeus ECO-TECH` 14}

\section{Kalmar, Sweden, November 24-26, 2014}

generates economic features lasting several years. Thus, the compliance with the polluter-pays principle should be part of a long-term time perspective.

The amount of collateral security is fixed based on the regulatory authority's estimate of the total expenditure to compliance with the terms of closure and post-treatment for a period set at 30 years. Moreover, the amount of collateral security must be indicated as a basic amount per ton of waste landfilled.

By removal of landfilled waste, the planned, long-termed economic features are disrupted. Thereby, it is reasonable to perform an amount written down of the collateral security equivalent to the expected cost related to the waste.

In this connection, it should be noted that the legislation permits various types of collateral security and, furthermore, certain types of collateral security does not necessarily convert to cash payment.

It is the landfill site's supervising authority that makes the decision on the amount of collateral security and, thus, whether the collateral security should be written down.

Obviously, a concrete evaluation of how much the collateral security can be written down by removal of waste must be conducted. For this calculation example, the entire basic amount per ton of landfilled waste is set off.

\section{No. 10: Aftercare length uncertainty}

Landfilling is generally based on the assumption that the landfilled waste will achieve "final storage quality" within a reasonable period of time. Final storage quality represents a condition at which the leachate from the landfill has become acceptable in the surrounding environment, allowing the site to be safely abandoned without active environmental protection measures. Final storage quality is not a very well defined concept. Due to the lack of reliable data and research, little is known about the time needed to reach the final storage quality.

The EU Landfill Directive (1999/31/EC) requires (in Article 13 c)) that "after a landfill has been definitely closed, the operator shall be responsible for its maintenance, monitoring and control in the after-care phase for as long as may be required by the competent authority, taking into account the time during which the landfill could present hazards.” In Article 10 of the Landfill Directive Member States are required to ensure that financial security is in place to include the cost of the after-care of a closed landfill site for a period of "at least 30 years". Despite the formulation, it has become customary for many landfill operators e.g. in Denmark to use 30 years of after-care as a default condition when calculating the gate fees for acceptance of waste at a landfill. This means that if the aftercare period exceeds 30 years (which for many landfills seems likely), maintenance, monitoring and control is still the responsibility of the operator, but the financial security may be insufficient to cover the costs associated with the extension of the aftercare period. This problem could be anticipated and possibly remedied if a reasonably accurate estimate could be made of the aftercare period for a given landfill. 


\section{Linnaeus ECO-TECH` 14}

\section{Kalmar, Sweden, November 24-26, 2014}

However, in order to assess the duration of the aftercare period for a landfill, it is necessary to determine the conditions under which "the competent authorities consider the landfill likely to cause a hazard to the environment" (Article $12 \mathrm{~d}$ ) in the Landfill Directive). The Landfill Directive does not provide any specific guidance on how to determine that the landfill has reached a stage where the active management associated with the after-care period can be discontinued and the landfill can be "left on its own" with only passive environmental protection systems in place.

Estimating the duration of the aftercare period for a landfill is at best an extremely difficult task, and if the goal to be reached is not known, it becomes virtually impossible. In general, the exact criteria to be met are likely to be site-specific and depend on the type of landfill in question and on vulnerability of the surrounding environment

The costs associated with the management of leachate and monitoring of groundwater/surface water and leachate during the aftercare period, i.e. the period from the completion of landfilling until the achievement of final storage quality, should be incorporated into the gate fee paid by the waste producers. Hence, the total costs of landfilling should depend on the duration of the aftercare period, which is described as a period of at least 30 years according to the landfill directive. As a result, landfill owners (society) and not necessarily waste producers will have to cover the extra costs associated with any extension of the aftercare period.

It is highly probable that an aftercare period of 30 years for a hazardous landfill is inadequate. Research results /8//9/ point out that this period ought to be at least 100 years or more for different chemical substances, which could have a positive value for the project cost. However, it is still very theoretical and more research is needed.

\section{Calculation on the effects on the change in aftercare length (2010 prices) /12/}

Aftercare cost are $€ 45.870$ per year (hazardous waste)

If landfilling works as planned this means:

30 years of $€ 45.870=€ 1.300 .000$

If the period is 50 years:

50 years of $€ 45.870$ per year $=€ 2.290 .000$ (Deficit $€ 990.000$ )

If the period is 100 years:

- 100 years of $€ 45.870$ per year $=€ 4.500 .000$. (Deficit $€ 3.200 .000$ )

What is the change in Landfill Mining costs and revenues if the financial provision is not sufficient for 30 years and how is taken into account is shown in the next part. 


\section{COST-BENEFIT CALCULATION}

Based on the aforementioned preconditions and scenarios, the economics related to LFM of shredder residue can be calculated.

In the following outline, cost is indicated in euro terms per removed ton of shredder residue with the stated distribution of the amounts of shredder residue removed respectively for recycling, incineration, and (re-) landfilling.

\section{Three Scenarios}

Removal of shredder residue will take place under different economic conditions contingent on when the waste is landfilled or removed. Thereby, the economic evaluation is based on the following three scenarios including sub-scenarios as shown in table 2.
Scenario I: The waste is removed after 2015 in which both waste taxes and waste heat taxes are fully implemented. It is assumed that offsetting waste tax on removal is not possible. The size fraction is carried out at the landfill site and the fine fraction is re-landfilled without further treatment. Other fractions are taken to a recycling site in which metal and energy are recycled.

Scenario Ia: The waste is removed after 2015 in which both waste taxes and waste heat taxes are fully implemented. It is assumed that there is scope for offsetting waste tax on removal equivalent to the proportion returned to the landfill site. All excavated shredder residue is removed from the landfill site. Metal and energy are recycled and the treated fine fractions are returned to the landfill site.

Scenario II: The waste is removed after 2015 in which both waste taxes and waste heat taxes are fully implemented. It is assumed that other hazardous waste is landfilled by which the possibility of reimbursement of the waste tax can be included in the evaluation. The size fraction is carried out at the landfill site and the fine fraction is re-landfilled without further treatment. Other fractions are taken to a recycling site in which metal and energy are recycled.

Scenario III: There will be an excavation and mining of metal from landfilled shredder residue. The treatment will take place at an appointed external site. Metal is recycled, whereas, everything else is re-landfilled. It is assumed that other hazardous waste is landfilled by which full tax offsetting on removed waste may occur.

Scenario IIIa: There will be an excavation and mining of metal from landfilled shredder residue. The treatment will take place at a landfill site. Metal is recycled, whereas, everything else is re-landfilled. It is assumed that other hazardous waste is landfilled by which full tax offsetting on removed waste may occur.

Table 2: Scenarios 


\section{Linnaeus ECO-TECH 14}

Kalmar, Sweden, November 24-26, 2014

\section{Economics - Reno Djurs I/S}

At Reno Djurs approximately 300.000 tonnes of shredder residues have been landfilled since 1996. There is a lot of landfilling capacity left for approximately 100 years of landfilling. The landfill is owned by two municipalities and located in Jutland in the countryside 50 kilometres outside Aarhus, which is the second biggest city in Denmark.

\begin{tabular}{|c|c|c|c|c|c|}
\hline & $€ . /$ ton & $€ . /$ ton & $€ . /$ ton & $€ . /$ ton & $€ . /$ ton \\
\hline & $\begin{array}{l}\text { Scenario } \\
\text { I }\end{array}$ & $\begin{array}{l}\text { Scenario } \\
\text { Ia }\end{array}$ & $\begin{array}{l}\text { Scenario } \\
\text { II }\end{array}$ & $\begin{array}{l}\text { Scenario } \\
\text { III }\end{array}$ & $\begin{array}{l}\text { Scenario } \\
\text { IIIa }\end{array}$ \\
\hline \multicolumn{6}{|l|}{ Costs } \\
\hline Excavation & 1.3 & 1.3 & 1.3 & 1.3 & 1.3 \\
\hline Sorting & 26.7 & 26.7 & 26.7 & 26.7 & 26.7 \\
\hline Transportation/removal & 20 & 20 & 20 & 20 & 20 \\
\hline Incineration & 49.3 & 49.3 & 49.3 & 49.3 & 49.3 \\
\hline Landfilling & 1.3 & 92 & 1.3 & 92 & 1.3 \\
\hline \multicolumn{6}{|l|}{ Revenue } \\
\hline Sale of Materials (avg.) & -46.7 & -46.7 & -46.7 & -46.7 & -46.7 \\
\hline $\begin{array}{l}\text { New landfill capacity } \\
\text { or volume }\end{array}$ & -2.7 & -2.7 & -2.7 & -2.7 & -2.7 \\
\hline Landfill Tax & 0 & -63.3 & -63.3 & -63.3 & -63.3 \\
\hline Financial Provision & -12.7 & -12.7 & -12.7 & -12.7 & -12.7 \\
\hline Sorting Degree & $\%$ & $\%$ & $\%$ & $\%$ & $\%$ \\
\hline Recycling & 5 & 5 & 5 & 5 & 5 \\
\hline Incineration & 50 & 50 & 50 & 0 & 0 \\
\hline Landfilling & 45 & 45 & 45 & 95 & 95 \\
\hline \multirow[t]{2}{*}{ Actual costs } & $€$ €./ton & $€ . /$ ton & $€ . /$ ton & $€ . /$ ton & $€ . /$ ton \\
\hline & $\begin{array}{l}\text { Scenario } \\
\text { I }\end{array}$ & $\begin{array}{l}\text { Scenario } \\
\text { Ia }\end{array}$ & $\begin{array}{l}\text { Scenario } \\
\text { II }\end{array}$ & $\begin{array}{l}\text { Scenario } \\
\text { III }\end{array}$ & $\begin{array}{l}\text { Scenario } \\
\text { IIIa }\end{array}$ \\
\hline \multicolumn{6}{|l|}{ Costs } \\
\hline Excavation & 1.3 & 1.3 & 1.3 & 1.3 & 1.3 \\
\hline Sorting & 26.7 & 26.7 & 26.7 & 26.7 & 26.7 \\
\hline Transportation & 11 & 20 & 11 & 20 & 0.9 \\
\hline Costs incineration & 24.7 & 24.7 & 24.7 & 0 & 0 \\
\hline Costs landfilling & 0.9 & 41.5 & 0.9 & 87.5 & 1.3 \\
\hline \multicolumn{6}{|l|}{ Revenue } \\
\hline Sale of Materials (avg.) & -46.7 & -46.7 & -46.7 & -46.7 & -46.7 \\
\hline $\begin{array}{l}\text { New landfill capacity } \\
\text { or volume }\end{array}$ & -1.5 & -1.5 & -1.5 & -0.1 & -0.1 \\
\hline Landfill Tax & 0 & -28.5 & -34.8 & -63.3 & -3.3 \\
\hline
\end{tabular}




\begin{tabular}{|l|l|l|l|l|l|}
\hline Financial Provision & -6.9 & -12.7 & -6.9 & -12.7 & -0.7 \\
\hline Total Costs LFM & & & & & \\
\hline
\end{tabular}

Table 3: Cost-benefit calculation, Reno Djurs I/S

\section{CONCLUSION}

The purpose with this article has been to show what main factors that influences on the economics of landfill mining. It's very hard to describe all the costs and revenues that influence on a project. The reality is often very different from what you predict (before) behind the desk. As soon as you start an excavation, the situation often change and unexpected things happens which might affect the economics.

Sale of excavated materials such as metals is a very important factor and considered as one of the most significant factors that contributes positive to the total economics of a project.

This study also shows that the location of the landfill represents a very big value. Landfills that have a good and central location might influence more on the economics than a location elsewhere. This would also effect in a more positive way if the excavation should lead to a later sale of the location in order to build new houses etc. for re-sale.

Finally if we count in the saved aftercare costs which of course are very uncertain and still on a theoretical stage then this could have a positive value for the project cost.

\section{REFERENCES}

/1/ Hansen J.B, Hyks J., Ahmed N, Wenzel H., Wellendorph P., Nedenskov J., Andersen F., Thrane J., Therkildsen M. Lavteknologisk genanvendelse af ressourcer i deponeret shredderaffald via størrelsesfraktionering. Miljøprojekt nr. 1440, 2012.

/2/ Hansen J.B, Hyks J., Ahmed N, Wenzel H., Wellendorph P., Nedenskov J., Andersen F., Thrane J., Therkildsen M, Landfill Mining of Shredder residues, Sardinia 2013, Fourteenth International Waste Management and Landfill Symposium

/3/ Rosendal R., Landfill Mining - Process, Feasibility, Economy, Benefits and Limitations, Denmark., RenoSam 2009

/4/ Van der Zee D.J., Achterkamp M.C. and de Visser B.J. (2004) Assessing the market opportunities of landfill mining. Waste Management, 24, 795804.

/5/ Van Vossen W.J., Prent O.J. (2011) Feasibility study - Sustainable material and energy recovery from landfills in Europe. Proceedings of the Thirteenth International Waste Management and Landfill Symposium, Sardinia 2011.

/6/ Bosmans A., Vanderreydt I., Geysen D. and Helsen L. (2011) The crucial role of Waste-to-Energy technologies in enhanced landfill mining: a technology review. Journal of Cleaner Production. Article in press. 
/7/ Danmark uden affald -Ressourceplan for affaldshåndtering 2013-2018, Vejledning fra Miljøstyrelsen nr. 4, 2014

/8/ Antonellis, D.G, Verlee, N.L (2011): Estimation of the Aftercare Period of Danish Landfills. Worchester Polytechnic Institute

/9/ Hansen J.B, Hyks J., Hjelmar O. (2011) Deponering af shredderaffald Undersøgelse af driftsforhold til nedbringelse af efterbehandlingsperioden, Statusrapport 2010, DHI

/10/ Cossu, R., Motzo, G. M., Laudadio, M. (1995), "Preliminary Study for a Landfill Mining Project in Sardinia”, Procs. Sardinia 95, 5th International Landfill Symposium, Cagliari, Vol. III, pp. 841-850

/11/ Hogland, W. (2002) Remediation of an Old Landfill Site, Soil Analysis, Leachate Quality and Gas Production , ESPR Special issue 1 (2002) pp 4954

/12/ Sikkerhedsstillelse og grundbeløb på deponeringsanlægget ved Glatved for 2011-12, Cowi A/S 